\title{
Juvenile Greenland Halibut (Reinhardtius hippoglossoides) growth in the context of rising temperature in the Estuary and Gulf of St. Lawrence
}

\author{
Leopold Ghinter ${ }^{1}$, Yvan Lambert ${ }^{2}$ and Céline Audet ${ }^{1}$ \\ ${ }^{1}$ Institut des Sciences de la Mer, Université du Québec à Rimouski, 310, allée des \\ Ursulines, Rimouski, QC, G5L 3A1, Canada \\ ${ }^{2}$ Institut Maurice Lamontagne, Pêches et Océans Canada, 850 route de la Mer, C.P. 1000, \\ Mont-Joli, QC, G5H 3Z4, Canada
}

Corresponding author:

Léopold Ghinter

Institut des Sciences de la Mer (ISMER)

Université du Québec à Rimouski (UQAR)

310 allée des Ursulines

Rimouski (Québec)

Canada

G5L 3A1

Tel.: +1 4187231986x1392

fax: +14187241842

E-mail address: leopold.ghinter@uqar.ca

Secondary E-mail address: leopold.ghinter@hotmail.fr 


\section{Abstract}

2 In a context of climate change, understanding the influence of temperature on fish species

3 growth is important for the management of fisheries. The effect of increasing temperature on

4 the growth of juvenile Greenland halibut (Reinhardtius hippoglossoides), a cold-water

5 species, circum-continental in the Arctic, was investigated on juveniles that had been captured

6 in the wild and kept in captivity. Mortality rate increased with higher temperature, from $4.5 \%$

7 at $4.0^{\circ} \mathrm{C}$ to $15.2 \%$ at $7.5^{\circ} \mathrm{C}$. Relative growth (normalized in degree-days) was lower at $7.5^{\circ} \mathrm{C}$

8 than at the two other temperatures tested. Food conversion efficiency, muscle energy content,

9 and the Fulton condition index were not influenced by temperature, but food intake

10 significantly increased over time at $5.5^{\circ} \mathrm{C}$. No clear difference in growth trajectories between

11 sexes was highlighted. Overall, the results suggest that optimal temperature conditions were

12 exceeded at $7.5^{\circ} \mathrm{C}$ and that any further increase in temperature would significantly decrease

13 survival and impair juvenile growth. With the current deep-water warming trends in the

14 Estuary and Gulf of St. Lawrence, recruitment and commercial fishing of Greenland halibut

15 may be impaired in the near future.

16 Keywords: Greenland Halibut, growth, temperature, juveniles, fisheries, mortality

\section{1. Introduction}

18 Among all factors influencing fish physiology, temperature is certainly one of the most

19 important. In ectotherms, metabolic processes are closely linked to water temperature (Fry,

20 1971; Fonds et al., 1992; Burel et al., 1996). Thus, fish growth is temperature-dependent (e.g.,

21 Brett and Groves, 1979; Jobling, 1993). A rise in temperature is usually accompanied by an

22 increase in basal maintenance costs and an increase in the efficiency of metabolic processes

23 (Xiaojun and Ruyung, 1992; Pörtner et al., 2010; Horodysky et al., 2015). It is generally

24 observed that growth and temperature are positively correlated when temperatures are below 
an optimum that varies among species, but that any further increase beyond that optimum destabilizes metabolism and leads to a reduction in growth (Fonds et al., 1995; Neuheimer et al., 2011).

Interrelationships between temperature, metabolism, and growth are complex. When basal metabolic rate increases due to a rise in temperature, fish may compensate by consuming more food (Fonds et al., 1992; Russel et al., 1996), by adjusting their food conversion efficiency (Russel et al., 1996; Imsland et al., 2001; Van Ham et al., 2003), and/or by modifying energy assimilation efficiency (Xiaojun and Ruyung, 1992; Russel et al., 1996). Without proper compensation, the scope for growth should decrease while basal metabolic needs increase (Cynoglossus semilaevis, Fang et al., 2010). In laboratory studies on flatfish, temperature and food availability have been identified as major factors influencing growth rate (Pleuronectes platessa, Platichthys flesus, Fonds et al., 1992; Paralichthys olivaceus, Fonds et al., 1995; Scophthalmus maximus, Van Ham et al., 2003; Cynoglossus semilaevis, Fang et al., 2010).

Fish are remarkably sensitive to temperature changes (Steffel et al., 1976; Claireaux et al., 1995), and Greenland halibut (Reinhardtius hippoglossoides) has shown shifts in its distribution that are associated with changes in bottom water temperatures (Morgan et al., 2013; Wheeland and Morgan, 2019). Over the last few decades, bottom water temperatures in the Estuary and Gulf of St. Lawrence (EGSL) have been rising due to increased warm water pulses entering through Cabot Strait (Galbraith et al., 2019). Bottom waters of the St. Lawrence Estuary, the main nursery of Greenland halibut in the EGSL (Ait Youcef et al., 2013), have increased by nearly $1^{\circ} \mathrm{C}$ between 2010 and 2018 , from 3.56 to $4.60^{\circ} \mathrm{C}$ at $200 \mathrm{~m}$ and from 4.73 to $5.63^{\circ} \mathrm{C}$ at $300 \mathrm{~m}$. Since 2015 , these changes have been particularly notable, with average temperatures above $4.5^{\circ} \mathrm{C}$ and $5.4^{\circ} \mathrm{C}$ at $200 \mathrm{~m}$ and $300 \mathrm{~m}$, respectively, while the 1981-2010 averages were $3.87 \pm 0.36^{\circ} \mathrm{C}$ and $4.97 \pm 0.23^{\circ} \mathrm{C}$, respectively (Galbraith et al., 
2019). In 2015, a reduction of $45 \%$ in the growth of two-year-old juveniles was observed

51 (DFO, 2019).

52 Greenland halibut is a species, circum-continental in the Arctic, that inhabits cold ( -0.5 to $6^{\circ} \mathrm{C}$; Bowering and Nedreaas, 2000) and deep waters generally between 130 and $1600 \mathrm{~m}$ and

54 sometimes to $2200 \mathrm{~m}$ (Scott and Scott, 1988; Boje and Hareide, 1993; Bowering and Power, 1995; Bowering and Nedreaas, 2000). In flatfish, juvenile growth is determinant for 56 recruitment (e.g., Van der Veer et al., 1994, 2000, 2015). This is especially true for Greenland 57 halibut, which is characterized by slow growth, late maturity, and a long juvenile period (Morgan et al., 2003; Treble et al., 2008; Albert, 2016). The EGSL population is one of the southernmost in the species' range, with bottom temperatures among the warmest where

60 Greenland halibut is found. The growth rates of juveniles in the EGSL are the highest 61 recorded for Greenland halibut (Ait Youcef et al., 2015). Temperature and food abundance 62 are the main factors explaining this characteristic (Bowering, 1983; Ait Youcef et al., 2015). 63 Based on the absence of a temperature effect on length increment between 1- and 2-year-old 64 juveniles despite differences of $1.5^{\circ} \mathrm{C}$ among areas and periods studied, Ait Youcef et al. 65 (2105) suggested that the optimal temperature range for juvenile growth may have been 66 reached in the EGSL. In such a scenario, and in the current context of warming waters of the 67 St. Lawrence, temperature conditions could become deleterious for juvenile growth and 68 impair recruitment.

69 Greenland halibut is a species with high commercial value and is subjected to a sustained 70 fishery across the North Atlantic (Victorero et al., 2018). Changes in the structure of the 71 population have already been observed, especially since 2015 , with decreases in juvenile 72 abundance and growth as well as a sharp decrease in the number of fish above the minimal 73 catch size in 2017 and 2018 (Bourdages et al., 2016; DFO, 2019). Along with the 74 establishment of a minimum catch size of $44 \mathrm{~cm}$ since the mid-1990s, changes in growth due 
to temperature changes could have a considerable impact on the biomass available for capture and therefore on the Greenland halibut fishery.

In the present study, we tested the effect of temperature on juvenile growth using juveniles captured in the wild and acclimated to controlled conditions. The temperature conditions tested were $4.0,5.5$, and $7.5^{\circ} \mathrm{C}$, which would allow us to compare current field conditions as well as a temperature increase that is anticipated in the near future (Galbraith et al., 2019). Our hypothesis is that the temperature conditions for optimal growth will be exceeded at $7.5^{\circ} \mathrm{C}$

\section{Material and methods}

\subsection{Capture, rearing conditions, and experimental design}

Greenland halibut juveniles were caught in the St. Lawrence Estuary $\left(48^{\circ} 39^{\prime} 11^{\prime \prime} \mathrm{N}, 68^{\circ} 28^{\prime}\right.$ $\left.37^{\prime \prime} \mathrm{W}\right)$ at the end of May in 2016 and 2017. Captures were made aboard the CCGS Leim with a Comando-type trawl ( $3 "$ trawl bucket; $2 "$ mesh size extension and pocket). The tows lasted 30 minutes and had a speed of 2-3 knots. In May 2016, depths varied between 175 and $275 \mathrm{~m}$, with most captures at $235 \mathrm{~m}(\mathrm{n}=210 ;$ mass $=135.7 \pm 52.8 \mathrm{~g}$; length $=25.7 \pm 3.2 \mathrm{~cm})$; in May 2017, depths were between 162 and $333 \mathrm{~m}$ and most captures at $324 \mathrm{~m}(\mathrm{n}=243$; mass $=175.5 \pm 57.5 \mathrm{~g}$; length $=28.4 \pm 3.0 \mathrm{~cm})$. Juveniles between 20 and $32 \mathrm{~cm}$ were selected. According to Ait Youcef et al. (2015) and Bourdages et al. (2016), these lengths should correspond to two-year-old juveniles. Fish were driven the $34 \mathrm{~km}$ from Rimouski to the Maurice-Lamontagne Institute (DFO; $\left.48^{\circ} 38^{\prime} 25^{\prime \prime} \mathrm{N}, 68^{\circ} 9^{\prime} 21^{\prime \prime} \mathrm{W}\right)$ in insulated aerated tanks. Wild fish were acclimated to captivity conditions for two months at $5.0^{\circ} \mathrm{C}$, which corresponds to the temperature at which juveniles were captured. During this period, fish were trained to feed in captivity and post-capture mortalities ended. The total post-capture mortality was $59 \%$ and 58\% in 2016 and 2017, respectively. 
Because of unbalanced sex ratios (higher numbers of females, $60 \%$ ), the experiment was run on two consecutive years with new fish captured each spring. At the end of the acclimation period (July), 10 juveniles were sacrificed at random for histological and physiological measurements. The rest of the individuals (200 in 2016 and 233 in 2017) were randomly placed in $850 \mathrm{~L}$ circular tanks ( 4 tanks per temperature, per year: total of 8 per experimental temperature conditions) where the temperature was gradually adjusted over $2-3$ days $\left(-0.5^{\circ} \mathrm{C}\right.$ $\left.\mathrm{d}^{1}\right)$ to obtain the three targeted temperatures $\left(4.0^{\circ} \mathrm{C}[4.1 \pm 0.3], 5.5^{\circ} \mathrm{C}[5.5 \pm 0.3]\right.$, or $7.5^{\circ} \mathrm{C}$ $[7.5 \pm 0.3])$. Lengths and masses were similar among the three temperature treatments at the beginning of the experiments (Table 1). According to Ait Youcef et al. (2015), 4.0 and $5.5^{\circ} \mathrm{C}$ represent, respectively, the lowest and the highest part of the range characterizing the average bottom temperatures where Greenland Halibut juveniles are usually captured during Department of Fisheries and Oceans Canada (DFO) surveys in the EGSL. In the current context of deep-water warming in the EGSL, $7.5^{\circ} \mathrm{C}$ was chosen as the highest temperature. The average number of fish per tank was 18 and varied from 13 to 25 juveniles, for an average density of $2.1 \pm 0.7 \mathrm{~kg} \mathrm{~m}^{-2}\left(1.2-3.65 \mathrm{~kg} \mathrm{~m}^{-2}\right)$. Rearing tanks were supplied with natural seawater $\left(10 \mathrm{~L} \mathrm{~min}^{-1}\right.$, salinity $\left.27.2 \pm 1.6\right)$ and oxygenated with bubblers (oxygen saturation $>80 \%$ ). Because juveniles are found in mesopelagic habitats (Ait Youcef et al., 2013) with small measurable quantities of light (disphotic zone), low intensity (30 \pm 17 lux) red light was provided that followed natural photoperiod variations at this latitude. Greenland halibut juveniles were fed individually to satiety twice a week with capelin (Mallotus villosus) and shrimp (Pandalus borealis); once a month, multivitamin-enriched additives (Vita- $\mathrm{Zu}$ Small Bird Tablet, no Vitamin A added \# 5TLC, Mazuri $\left.{ }^{\circledR}\right)$ that are essential for immune system development were added to the diet. The growth survey lasted for one year.

For the 2016-2017 experiment, final sampling data showed that the sex ratio was unbalanced in favour of females. The decision was then made to use the same protocol on juveniles in the 
124 2017-2018 experiment to increase the number of males to be sampled. We used similar 60:40

125 female:male ratios for the two experiments and among the three temperatures tested. Total 126 mortalities during these two experimental years was $10 \%$.

127 Experimental methods complied with the regulations of the Canadian Council on Animal

128 Care and were approved by the Maurice-Lamontagne Institute animal care committee.

\section{$129 \quad 2.2$ Samplings}

130 Growth rate was monitored three times during the year: July, December, and July of the

131 following year. At each sampling time, all fish were anaesthetized with a solution of

132 metomidate (Mattson and Riple, 1989; metomidate hydrochloride, Aquacalm, $5 \mathrm{mg} \mathrm{L}{ }^{-1}$,

133 Western Chemical Inc., Washington, USA), measured to the nearest $0.1 \mathrm{~cm}$, and weighed to

134 the nearest $0.1 \mathrm{~g}$. We sacrificed 10 fish per treatment at each sampling date, but due to the

135 unbalanced sex ratio encountered in 2016-2017 experiment, this number was raised to 20 in

136 2017-2018. Sacrificed fish were anaesthetized in a solution of MS 222 (tricaine methane

137 sulfonate $0.18 \mathrm{~g} \mathrm{~L}^{-1}$, Sigma-Aldrich, Co., Missouri, USA, for $5 \mathrm{~min}$ ) between 12:00 and 17:00

138 to avoid possible biases associated with endocrine circadian rhythms. The individuals were

139 then weighed and measured. Blood was sampled from the caudal artery using a 23-gauge

140 needle and a $1 \mathrm{~mL}$ TB syringe (Becton Dickinson \& Co, New Jersey, USA), both previously

141 heparinized (ammonium heparin salt, Sigma-Aldrich, Co., Missouri, USA) in a heparin

142 solution at $100 \mathrm{U} \mathrm{mL}^{-1}$. Muscle and gonad samples were excised. Blood samples were

143 centrifuged for $3 \mathrm{~min}$ at $4.6 \mathrm{G}$ and plasma was frozen in liquid nitrogen and stored at $-80^{\circ} \mathrm{C}$.

144 Gonads were fixed in Bouin's solution (Sigma Aldrich, Co., Missouri, USA) and muscle

145 samples were immediately frozen in liquid nitrogen and stored at $-80^{\circ} \mathrm{C}$.

\section{$146 \quad 2.3$ Morphological calculations}

147 At three times during the year (July - beginning of the experiment; December; July - end of

148 the experiment), all fish were weighed and measured. Data were reported as the average 
149 weight and length per tank, and tank is the statistical unit ( $\mathrm{n}=8$ per treatment). To determine

150 growth relative to sex, only data on sacrificed fish are available because the lack of sexual

151 dimorphism prevented us from identifying sex in live juveniles. For these, $\mathrm{n}$ is the number of

152 fish because fish that were sacrificed were sampled from different tanks during the same 153 sampling time. Data are expressed in terms of degree-days to take into account the thermal

154 units accumulated under the different temperature conditions (Neuheimer and Taggart, 2007).

155 Fish condition was estimated using the Fulton condition index $(\mathrm{K})$ :

$$
\mathrm{K}=\left(\mathrm{W} / \mathrm{L}^{3}\right) \times 100
$$

with $\mathrm{W}$ being the total mass $(\mathrm{g})$ and $\mathrm{L}$ the total length $(\mathrm{cm})$ of fish. The use of the Fulton index was justified since we compared fish in the same size range.

\subsection{Feeding calculations}

160 Food intake (FI) and food conversion efficiency (FCE) were calculated for each experimental

161 tank. At each feeding, food was weighed (g) and uneaten food was collected, weighed, and

162 subtracted from the given food mass to estimate food ingested. The total amount of food 163 ingested was divided by the number of fish present for each feeding event and tank to 164 normalize data between tanks. The average FI per fish per day was then calculated for each

165 sampling interval. FCE was calculated by dividing the mass increment (mass difference 166 between two sampling dates) by FI per fish and expressed as a percentage.

\section{$167 \quad 2.5$ Physiological and histological measurements}

168 For physiological measurements, individuals were considered as the statistical unit. At 4.0 and

$1695.5^{\circ} \mathrm{C}$ in December 2016, no males were among the euthanized fish. Sexual maturity was

170 determined based on histological observations and sex steroid measurements. Gonads were

171 dehydrated in increasing concentrations of ethanol and embedded in metacrylate JB-4 solution

172 according to the protocol suggested by the manufacturer (Sigma-Aldrich, Co., Missouri, 
173 USA). The embedded gonadal tissue was sectioned in $3 \mu \mathrm{m}$ slices and stained with Lee's

174 methylene blue-basic fuchsin solution. The stage of testis and ovarian development was

175 determined for each individual according to Morrison (1990) and to Rideout et al. (2012),

176 respectively. For each individual, one histological section on three different slides was used to

177 discriminate the maturity stage. Sex steroid concentrations were determined using an RIA kit

178 for testosterone and 17ß-estradiol ( ${ }^{125}$ I RIA Kit \# 07-189102 and \# 07-138102, respectively,

179 MP Biomedicals, LLC, California, USA) and ELISA for 11-ketotestosterone (ELISA Kit \#

180 582751, Cayman Chemical, Inc., Michigan, USA). Undetectable values were assigned the

181 half-value of the smallest standard.

182 The water content of muscle (X) was determined after drying pieces of muscle for $48 \mathrm{~h}$ at $18365^{\circ} \mathrm{C}$ and converted into total muscle energy content ( $\mathrm{Y}, \mathrm{kJ}$ g of wet tissue ${ }^{-1}$ ) using the 184 relationship established for Greenland halibut juveniles by Ait Youcef (2013):

$$
\mathrm{Y}=61.7366-0.4568 \mathrm{X}
$$

Plasma cortisol was measured with an RIA kit $\left({ }^{125}\right.$ I RIA Kit \# 07-221106, MP Biomedicals,

187 LLC, California, USA) and used as a primary stress indicator (Mazeaud et al., 1977).

\subsection{Statistical analysis}

189 Normality and homogeneity of variances were verified by Kolmogorov-Smirnov and Levene

190 tests, respectively. No transformation of data was needed to meet these criteria except for

191 steroid data (11-ketotestosterone, 17ß-estradiol, and cortisol), which were log transformed

192 prior to statistical analysis. For linear regressions, normalities were tested on residuals and

193 residual variations were tested using ANOVAs.

194 Data were first analyzed including "year" as a fixed effect. Because both years showed similar

195 results, data from experiments A and B were pooled. Length and mass data were regressed

196 against degree-days and regression slopes were compared. Fulton condition index values were 
197 compared using one-way ANOVA (temperature) at each sampling date. Fulton condition

198 index was regressed against length per temperature and slope coefficients were compared. FI

199 and FCE were tested using repeated-measurements analysis of variance (ANOVAR;

200 temperature $\times$ period).

201 Physiological analyses were made on sacrificed fish. For the following analyses, individuals

202 were considered as the statistical unit, and sex could be identified. The effects of sex on 203 length and mass were regressed against degree-day units. Effects of sex on the Fulton

204 condition index were tested using one-way ANOVA at each sampling date. The effects of 205 temperature, sampling time, and sex on muscle energy storage and plasma cortisol were 206 analyzed using three-way ANOVAs excluding the first sampling date (July) because the 207 sacrificed fish were finishing the acclimation period and had not yet begun treatment. The 208 effects of temperature and sampling time on plasma concentrations of sexual steroid (11209 ketotestosterone in males and $17 \beta$-estradiol in females) were analyzed using two-way 210 ANOVAs, and the a posteriori Tukey test was used when significant factor effects were 211 found for comparison of means $(\alpha=0.05)$. Since cortisol data were heteroscedastic, we used 212 the Fisher LSD post-hoc test. Mortality was represented using the survival function of Kaplan 213 and Meier (1958); the Chi-square test was performed to test the effect of temperature; and the 214 Gehan Wilcoxon a posteriori test allowed us to identify the differences. Statistical analyses 215 were performed with Statistica software (Statsoft v.6.1, Oklahoma, USA).

216 3. Results

217 3.1 Survival, growth, and feeding

218 Survival of Greenland halibut juveniles varied according to the temperature treatment 219 throughout the experiment $\left(\mathrm{Chi}^{2}{ }_{2}=10.62, \mathrm{P}<0.01\right.$; Fig. 1$)$. Survival was lower at $7.5^{\circ} \mathrm{C}$ than 220 at $4.0^{\circ} \mathrm{C}(\mathrm{P}<0.05)$, and intermediate at $5.5^{\circ} \mathrm{C}(\mathrm{P}>0.05)$. Among the mortalities, the sex-ratio 221 (F:M) varied according to temperature. While it was $2: 4$ at $4.0^{\circ} \mathrm{C}$ and $7: 4$ at $5.5^{\circ} \mathrm{C}$, many more 
222 females died at $7.5^{\circ} \mathrm{C}$, with a ratio $16: 3$ (Fig. 1). Greenland halibut juveniles were similarly

223 sized among the three temperatures on the initial sampling date (Table 1). While mass and 224 length trajectories were similar at 4.0 and $5.5^{\circ} \mathrm{C}$, they were significantly lower at $7.5^{\circ} \mathrm{C}$ than 225 at 4.0 and $5.5^{\circ} \mathrm{C}$ (Table 2; Fig. 2A, B).

226 The Fulton index was not influenced by temperature (Table 3; slope comparison $F_{2,66}=1.47$, $227 \mathrm{P}>0.05$, and covariance analysis $\left.\mathrm{F}_{2,68}=1.20, \mathrm{P}>0.05\right)$, but a clear size effect was identified, 228 with the Fulton condition index increasing with fish size (linear regression: $\mathrm{R}^{2}=0.72, \mathrm{~F}_{1,70}=$ 229 179.69, P < 0.001; Fig. 3). Food intake (FI) was significantly higher from December to July 230 than during the first rearing period at $5.5^{\circ} \mathrm{C}$, but this was not the case for fish at 4.0 or $7.5^{\circ} \mathrm{C}$ 231 (Table 4; Temperature $\times$ Period of sampling, $\mathrm{F}_{2,21}=5.19, \mathrm{P}<0.05$ ). Temperature had no 232 effect on FCE (Temperature $\times$ Period, $\mathrm{F}_{2,21}=1.13, \mathrm{P}>0.05 ;$ Temperature, $\mathrm{F}_{2,21}=0.32$, $233 \mathrm{P}>0.05)$, but it was significantly lower during the second rearing period $(26.0 \pm 2.6 \%$ vs. $23423.4 \pm 3.6 \%$, respectively; Period of sampling, $\left.\mathrm{F}_{1,21}=4.48, \mathrm{P}<0.05\right)$.

\subsection{Physiological and histological measurements}

236 The terminal samplings allowed us to identify the sex and then to study the two sexes

237 separately. Mass and length of males and females were similar at the beginning of the 238 experiment (Table 5). While length and mass did not differ over time between females and 239 males at 4.0 and $7.5^{\circ} \mathrm{C}$, length increased more rapidly at $5.5^{\circ} \mathrm{C}$ in females than in males but 240 mass increases were similar (Table 6; Fig. 4). At the beginning of the experiment, females and 241 males showed similar condition indexes (Table 7) whereas females had a significantly higher 242 Fulton condition index than males in December and after one year (Table 7).

243 Males were still sexually immature in December, a period of the year during which gonad 244 ripening occurs in Greenland halibut. Gonad histology revealed that no males showed signs of 245 gonad maturation at 4.0 or $5.5^{\circ} \mathrm{C}$ and only one male out of 15 sampled at $7.5^{\circ} \mathrm{C}$ in December 246 was at the very beginning of the maturation process. Plasma testosterone remained 
247 undetectable during the whole experiment at the three rearing temperatures. However,

248 temperature did not affect plasma 11-ketotestosterone concentration, which remained stable 249 during the experiment despite the growth of males, with an overall mean of $250 \quad 79.16 \pm 127.85 \mathrm{pg} \mathrm{mL}^{-1}$.

251 All female gonads were still immature in December. Plasma testosterone also remained 252 undetectable throughout the experimental period and for all temperature treatments. Plasma $25317 \beta$-estradiol concentration was not influenced by temperature, but it was almost twice as 254 high at the end of the experiment in July than in December $\left(149.7 \pm 115.4 \mathrm{pg} \mathrm{mL}^{-1}\right.$ vs. $85.7 \pm$

$\left.25541.5 \mathrm{pg} \mathrm{mL}^{-1}\right)$. Because there was no temperature effect on $17 \beta$-estradiol, females were pooled 256 and their plasma $17 \beta$-estradiol was regressed against their length (Fig. 5). The increase in 257 plasma $17 \beta$-estradiol throughout the experiment was clearly associated with the growth of 258 female juveniles during the experiment (Fig. 5).

259 Sex had no effect on the content of energy stored in muscle tissue or on plasma cortisol levels.

260 A global increase in energy stored in muscle tissue was notable between the fish at the 261 beginning of the experiment $\left(4.23 \pm 0.74 \mathrm{~kJ} \mathrm{~g}\right.$ of wet muscle $\left.{ }^{-1}\right)$ and those sampled on the other 262 two sampling dates (December and July - end of experiment; $5.09 \pm 0.93 \mathrm{~kJ} \mathrm{~g}$ of wet 263 muscle- ${ }^{1}$; Table 8). However, temperature conditions had no effect on this variable.

264 Temperature had a slight effect on plasma cortisol, and juveniles kept at $5.5^{\circ} \mathrm{C}$ showed lower 265 plasma cortisol concentrations $\left(80.9 \pm 135.7 \mathrm{ng} \mathrm{mL}^{-1}\right)$ than fish reared at 4.0 or $7.5^{\circ} \mathrm{C}(93.2 \pm$ $266122.6 \mathrm{ng} \mathrm{mL}^{-1}$; Table 8).

\section{4. Discussion}

268 The main objective of this work was to investigate in experimental conditions the potential 269 effect of current and anticipated temperatures in the EGSL on the growth of juvenile 270 Greenland halibut. Bottom temperatures in the EGSL are rising, and this tendency will 
continue in the coming years considering temperatures measured in incoming waters and the

272 renewal time of water masses in this system (Gilbert, 2004; Galbraith et al., 2019). Our results

273 demonstrate that increasing temperature could seriously impair juvenile growth and survival.

274 Mortality varied according to temperature: it was higher at $7.5^{\circ} \mathrm{C}(15.2 \%)$ than at $4.0^{\circ} \mathrm{C}$

$275(4.5 \%)$ and intermediate at $5.5^{\circ} \mathrm{C}(10.1 \%)$. In the wild, Sünksen et al. (2010) showed that the

276 instantaneous mortality rate from 1 to 2 years old was positively correlated with temperature

277 in juvenile Greenland halibut. In our study, many more females held at $7.5^{\circ} \mathrm{C}$ died compared

278 males (16:3), suggesting that females are more sensitive to elevated temperatures.

279 Despite a greater quantity of thermal energy received in degree-days at $7.5^{\circ} \mathrm{C}$ relative to $5.5^{\circ} \mathrm{C}$

280 and $4.0^{\circ} \mathrm{C}$, juvenile Greenland halibut growth did not show the increase expected for

281 ectotherms. This result suggests that optimal temperature conditions may have been exceeded

282 at $7.5^{\circ} \mathrm{C}$ and that any further increase in observed temperatures in the EGSL would have a

283 deleterious impact on metabolic processes and growth. Growth by thermal energy was similar

284 at 4.0 and $5.5^{\circ} \mathrm{C}$, and so we expected a difference in size at the end of the one-year

285 experiment since fish reared at $5.5^{\circ} \mathrm{C}$ received more energy over time. At the end of the

286 experiment, the difference in degree-days between the 4.0 and $5.5^{\circ} \mathrm{C}$ conditions was 540

287 degree-days. Greenland halibut is considered to be a slow-growing species, and it is possible

288 that the experiment was not long enough to observe differences at the two lower temperatures.

289 It is also possible that these two temperatures were within or close to the optimal temperature

290 range for growth of Greenland halibut juveniles, so differences in growth would be hardly

291 noticeable and may have plateaued. Indeed, in laboratory studies on S. maximus juveniles fed

292 the same ration, such plateaux were observed between 17 and $20^{\circ} \mathrm{C}$ (Burel et al., 1996) and

29316 and $22^{\circ} \mathrm{C}$ (Van Ham et al., 2003).

294 Except at $5.5^{\circ} \mathrm{C}$, where females had a greater increase in length than males, our results 295 differed from those obtained in a previous study (Ghinter et al., 2019), where females grew 
faster than males at $4.0^{\circ} \mathrm{C}$. It is possible that different durations of the experiments (ours was

297 one year, theirs 18 months) could explain these differences.

298 Food supply is also a major factor affecting growth, since it is generally assumed that food is 299 the "driving force" supplying the energy to invest in growth (Brett and Groves, 1979; Jobling, 300 1993). Food intake per fish is closely related to temperature (P. platessa and Platichthys 301 flesus, Fonds et al., 1992; S. maximus, Burel et al., 1996; Salmo salar, Handeland et al., 302 2008). However, the only significant food intake difference we observed was observed at $3035.5^{\circ} \mathrm{C}$, with an increase in feeding rate during the second part of the experiment. Interestingly, 304 this increase in feeding rate did not result in higher growth rate. The FCE, which reflects the 305 fraction of ingested food converted into growth in mass, is known to be influenced by 306 temperature and fish size (Hippoglossus hippoglossus, Björnsson and Tryggvadóttir, 1996;

307 Gadus morhua, Björnsson et al., 2001; Imsland et al., 2005; S. maximus, Van Ham et al., 308 2003; Salmo salar, Handeland et al., 2008). Here, it appears that only size is affected by FCE, 309 with a global decrease between the two sampling periods. FCE was variable among tanks, 310 especially during the second half of the experiment. A global decrease in FCE during juvenile 311 growth is consistent with previous results obtained on flatfish (S. maximus, Van Ham et al., 312 2003).

313 Muscle makes up about $37 \pm 4 \%$ of the body mass in juvenile Greenland halibut $<40 \mathrm{~cm}$ (Y.

314 Lambert, pers. obs.) and 42 to $51 \%$ in adults (calculated from Karl et al., 2018), so it plays an 315 important role in energy storage (Ait Youcef, 2013). Here, we only observed an overall 316 increase in muscle energy content between the beginning and the end of the experiment. This 317 rise reflects a positive effect of the experimental settings relative to the natural environment, 318 and especially that of the ad libidum diet. From December until the end of the experiment, all 319 juveniles reached a plateau after which neither temperature nor sex had any effect on muscle 320 energy content. The food supply was thus adequate to meet all energy needs, including basic 
maintenance metabolism and other needs, even at $7.5^{\circ} \mathrm{C}$, when basal energy demands should

322 have been higher. No individuals had to draw extra energy from their tissues. It is therefore 323 possible that better food assimilation (conversion of food energy into net energy available for 324 maintenance and growth) at higher temperatures occurred, as has been shown in other fish 325 species (Dicentrarchus labrax, Hidalgo et al., 1987; Russel et al., 1996; Silurus meridionalis, 326 Xiaojun and Ruyung, 1992).

327 Although long debated (see Bolger and Connolly, 1989; Lloret et al., 2014), especially 328 concerning application criteria, the Fulton condition index is a simple and widely used proxy 329 reflecting the "well-being" of a fish, with the general idea that a heavier weight for a given 330 length corresponds to better condition. The similar Fulton condition indices between all three 331 temperatures support the idea that the food supply met all the juveniles' energy needs. The 332 increase in the Fulton condition index throughout the experiment is related to the increase in 333 juvenile size. With allometric growth (the b-value of the weight-length relationship being 334 different from 3; Lloret et al., 2014), correlation between the condition factor and length is 335 expected (Bolger and Connolly, 1989; Cone, 1989); this has already been demonstrated in 336 juvenile Greenland halibut (Ait Youcef, 2013). Nevertheless, females showed higher Fulton 337 indexes than males throughout the experiment. This is consistent with the results of Ghinter et 338 al. (2019), where females, whose growth was greater, reached the maximum plateau faster 339 than males at $4.0^{\circ} \mathrm{C}$.

340 Plasma cortisol levels, a primary stress indicator (Mazeaud et al., 1977), were significantly 341 higher in juveniles kept at 4.0 and $7.5^{\circ} \mathrm{C}$ than at $5.5^{\circ} \mathrm{C}$, although the difference remained 342 small. In their study of salmonid fish (Salmo trutta and S. gairdneri), Pickering and Pottinger 343 (1989) measured responses to acute stress (handling or $1 \mathrm{~h}$ confinement) ranging from 40 to $344200 \mathrm{ng} \mathrm{mL}-1$. Thus, in view of our results, it seems that fish held at $5.5^{\circ} \mathrm{C}$ were slightly less 345 sensitive to manipulation than were those at the other two temperatures. Sensitivity to stress 
346 has been shown to vary according to sex in juvenile Greenland halibut (Ghinter et al., 2019),

347 but we found no effect of sex in our study.

348 Histological and hormonal analyses clearly showed that a rise in temperature did not promote 349 sexual maturation at a smaller size in either males or females. Sexual steroids remained at 350 very low concentrations despite the presence of significant variations. There are no data about 351 sexual steroid concentrations in adult Greenland halibut. In Atlantic halibut (H. hippoglossus), 352 a species that also reproduces during winter, plasma $17 \beta$-oestradiol concentrations in females 353 increased from less than $3000 \mathrm{pg} \mathrm{mL}^{-1}$ in summer to more than $20000 \mathrm{pg} \mathrm{mL}^{-1}$ during the 354 reproductive period (Methven et al., 1992), while it remained lower than $400 \mathrm{pg} \mathrm{mL}^{-1}$ in the 355 fish we surveyed. We did observe a gradual rise that must be due to the progressive and 356 increasing secretion of sex hormones along with the development of follicles, which takes 357 place throughout the growth of juveniles (Leucoraja ocellate, Sulikowski et al., 2005). 358 Testosterone concentrations remained undetectable in both sexes, and in males, 359 concentrations of 11-ketotesterone did not exceed $900 \mathrm{pg} \mathrm{mL}^{-1}$, which is far below the 360 concentrations reported for Atlantic halibut during milt release $\left(>2000 \mathrm{pg} \mathrm{mL}^{-1}\right.$, with peaks 361 up to $16000-180000$ pg mL-1; Methven et al., 1992; Norberg et al., 2001). Gonad histology 362 confirmed the absence of advanced differentiated germ cells in the testes and ovaries, and 363 none of the juveniles studied reached the adult stage during the survey. At the end of the 364 experiment—independent of the temperature conditions-only $4.0 \%$ of females exceeded 44 $365 \mathrm{~cm}$ and $28.1 \%$ of males were above $35 \mathrm{~cm}$, which are respectively the sizes at which $50 \%$ of 366 fish should have reached sexual maturity in the EGSL (DFO, 2018).

367 Very few studies on Greenland halibut have been pursued under laboratory conditions, 368 including experiments involving temperature conditions. However, the effect of temperature 369 on juvenile growth has already been addressed in the wild in some studies analyzing 370 oceanographic survey data. In the offshore waters west of Greenland, the mean lengths of the 
371 1- and 2-year-old Greenland halibut were positively correlated with ambient temperature,

372 which varied between 1.0 and $4.0^{\circ} \mathrm{C}$ (Sünksen et al., 2010). These authors found an average

373 increase in mean length of $1.6 \mathrm{~cm}^{\circ} \mathrm{C}^{-1}$ for 1 -year-old and $1.5 \mathrm{~cm}^{\circ} \mathrm{C}^{-1}$ for 2-year-old

374 juveniles. In the EGSL, in a narrow and upper range of temperatures among sites, surveys,

375 and years (mean annual bottom temperatures $4.95-5.14^{\circ} \mathrm{C}$ ), no correlation between juvenile

376 growth and temperature was noted, possibly because of the very stable temperature conditions

377 that prevail throughout the year (Ait Youcef et al., 2015).

378 It is important to keep in mind that our study was done under stable experimental conditions,

379 without food limitations or any other energy expenditure such as food foraging or predator

380 avoidance. In nature, an increase in temperature also means a decrease in dissolved oxygen. In

381 the St. Lawrence Estuary, these rates are already very low and close to the critical threshold

382 for this species (Dupont-Prinet et al., 2013). Thus, with increasing bottom temperatures,

383 dissolved oxygen levels could become dangerously low for the survival of juveniles. In the

384 wild, Greenland halibut carry out extensive vertical migrations (Vollen and Albert, 2008;

385 Albert et al., 2011) to feed on epibenthic and bathypelagic prey (Bowering and Lilly, 1992;

386 Dawe et al., 1998; Solmundsson, 2007; Dennard et al., 2009). This foraging activity, which is

387 metabolically very demanding, could be altered by the modification of abiotic parameters

388 generated by increased temperature. The consequences of increasing temperatures on growth,

389 survival, and thus recruitment to the population would be much greater than those predicted in

390 this experimental study, where dissolved oxygen was maintained above $80 \%$ saturation.

391 Greenland halibut, especially the young stages, have been shown to change their distribution

392 to maintain preferred thermal habitats, migrating deeper or shallower depending on

393 temperature conditions (Morgan et al., 2013; Wheeland and Morgan, 2019). Such migration

394 possibilities would be very limited in the EGSL due to the geography and bathymetry of this 395 region. 


\section{Conclusion}

Although the temperature was higher, no increase in juvenile growth occurred at $7.5^{\circ} \mathrm{C}$, as would be expected in ectotherms, so the optimal temperature range for growth might have been exceeded. The absence of significant variations in FI, FCE, and muscle energy reserves between temperatures suggest that food supply or/and assimilation efficiency in experimental conditions were sufficient to sustain growth and maintain condition at every temperature treatment.

These results are in accordance with the hypothesis of Ait Youcef et al. (2015), which stated that, within the EGSL, an optimal temperature of around $5.0^{\circ} \mathrm{C}$ would have been reached. It would also support hypotheses by Bowering (1983) and Ait Youcef et al. (2015), which stated that the higher growth rates recorded in the EGSL for this species would be partly due to ambient temperatures found in this region. However, the results of our study suggest that a further increase in bottom temperature could affect the commercial Greenland halibut fishery in the EGSL by decreasing fish growth and increasing natural mortality of juvenile fish.

\section{Funding}

This project was funded by the Natural Sciences and Engineering Research Council of Canada (NSERC Strategic grant No. STPGP/ 478827-2015 to L. Bernatchez, C. Audet, R. Tremblay, P. Sirois, Y. Lambert, M.J. Morgan, K. Praebel, and J. Boyer) and Fisheries and Oceans Canada (DFO).

\section{Authorship statements}

Ghinter: Conceptualization, Data curation, Formal analysis, Investigation, Methodology, Validation, Visualization, Writing - original draft.

Lambert: Conceptualization, Data curation, Funding acquisition, Investigation, Methodology, Resources, Supervision, Validation, Writing - review and editing. 
421 Audet: Conceptualization, Data curation, Funding acquisition, Investigation, Methodology,

422 Project administration, Resources, Supervision, Validation, Writing - review and editing.

423

424

425

427

430

\section{Acknowledgments}

The authors are grateful to J. Gagnon, S. St-Pierre, F. Tremblay, and Y. Gagnon for help with experiments and assistance in caring for fish, and to R. Gagné for her invaluable help in the laboratory and during samplings. They thank the research network Ressources Aquatiques Québec (Regroupement stratégique Fonds de recherche du Québec - Nature et technologies) for its financial and scientific support to this project.

\section{References}

Ait Youcef, W. 2013. Impacts de l'oxygène dissous sur la distribution spatiale, l'abondance et la croissance du flétan du groenland (Reinhardtius hippoglossoides) dans l'estuaire et la golfe du Saint-Laurent. Université du Québec à Rimouski. 145 pp.

Ait Youcef, W., Lambert, Y., and Audet, C. 2013. Spatial distribution of Greenland halibut Reinhardtius hippoglossoides in relation to abundance and hypoxia in the estuary and Gulf of St. Lawrence. Fisheries Oceanography, 22: 41-60.

Ait Youcef, W., Lambert, Y., and Audet, C. 2015. Variations in length and growth of Greenland Halibut juveniles in relation to environmental conditions. Fisheries Research, 167: $38-47$.

Albert, O. T. 2016. Growth and formation of annual zones in whole otoliths of Greenland halibut, a slow-growing deep-water fish. Marine and Freshwater Research, 67: 937-942. http://dx.doi.org/10.1071/MF15089.

Albert, O. T., Lambert, Y., Vollen, T., Freitas, C., and Heggebakken, L. 2011. Distinguishing pelagic and demersal swimming of deepwater flatfish by recording of body angles. 
Björnsson, B., and Tryggvadóttir, S. V. 1996. Effects of size on optimal temperature for 446 growth and growth efficiency of immature Atlantic halibut (Hippoglossus hippoglossus L.). Aquaculture, 142: 33-42.

Björnsson, B., Steinarsson, A., and Oddgeirsson, M. 2001. Optimal temperature for growth and feed conversion of immature cod (Gadus morhua L.). ICES Journal of Marine Science, 58: 29-38.

Boje, J., and Hareide, N.-R. 1993. Trial deepwater longline fishery in the Davis Strait, MayJune 1992. NAFO Scientific Council Research Document, 93/53: 1-6.

Bolger, T., and Connolly, P. L. 1989. The selection of suitable indices for the measurement and analysis of fish condition. Journal of Fish Biology, 34: 171-182.

Bourdages, H., Brassard, C., Desgagnés, M., Galbraith, P., Gauthier, J., Légaré, B., Nozères, C., Parent, E., Schwab, P. 2016. Preliminary results from the groundfish and shrimp multidisciplinary survey in August 2015 in the Estuary and northern Gulf of St. Lawrence. DFO Can. Sci. Advis. Sec. Res. Doc., 2016/004: v+87.

Bowering, W. R. 1983. Age, growth, and sexual maturity of Greenland halibut, Reinhardtius hippoglossoides (Walbaum), in the Canadian Northwest Atlantic. Fishery Bulletin, 81: 599-611.

Bowering, W. R., and Lilly, G. R. 1992. Greenland halibut (Reinhardtius hippoglossoides) off southern Labrador and northeastern Newfoundland (Northwest Atlantic) feed primarily on capelin (Mallotus villosus). Netherlands Journal of Sea Research, 29: 211-222.

Bowering, W. R., and Power, D. 1995. Spatial distribution of Greenland halibut (Reinhardtius hippoglossoides (Walbaum)) in the Labrador-eastern Newfoundland area of the 
Bowering, W. R., and Nedreaas, K. H. 2000. A comparison of Greenland halibut (Reinhardtius hippoglossoides (Walbaum)) fisheries and distribution in the Northwest and Northeast Atlantic. Sarsia, 85: 61-76.

Brett, J. R., and Groves, T. D. D. 1979. Physiological energetics. In: Bioenergetics and Growth, Fish Physiology, vol. VIII, pp. 280-352. Ed. by W.S. Hoar, D.J. Randall, J.R. Brett, Academic Press, London. 786 pp.

Burel, C., Person-Le Ruyet, J., Gaumet, F., Le Roux, A., Sévère, A., and Boeuf, G. 1996. Effects of temperature on growth and metabolism in juvenile turbot. Journal of Fish Biology, 49: 678-692.

Claireaux, G., Webber, D. M., Kerr, S. R., and Boutilier, R. G. 1995. Physiology and behaviour of free-swimming Atlantic cod (Gadus morhua) facing fluctuating temperature conditions. Journal of Experimental Biology, 198: 49-60.

Cone, R. S. 1989. The need to reconsider the use of condition indices in fishery science. Transactions of the American Fisheries Society, 118: 510-514.

Dawe, E. G., Bowering, W. R., and Joy, J. B. 1998. Predominance of squid (Gonatus spp.) in the diet of Greenland halibut (Reinhardtius hippoglossoides) on the deep slope of the northeast Newfoundland continental shelf. Fisheries Research, 36: 267-273.

Dennard, S. T., McMeans, B. C., and Fisk, A. T. 2009. Preliminary assessment of Greenland halibut diet in Cumberland Sound using stable isotopes. Polar Biology, 32: 941-945.

DFO. 2018. Assessment of Greenland Halibut in the Gulf of St. Lawrence (4RST) in 2016. DFO Can. Sci. Advis. Sec. Sci. Advis. Rep., 2017/049.

DFO. 2019. Assessment of the Gulf of St. Lawrence (4RST) Greenland Halibut stock in 2018. 
Dupont-Prinet, A., Vagner, M., Chabot, D., and Audet, C. 2013. Impact of hypoxia on the metabolism of Greenland halibut (Reinhardtius hippoglossoides). Canadian Journal of Fisheries and Aquatic Sciences 70: 461-469.

494

495

496

497

498

499

500

501

502

503

504

505

Fang, J., Tian, X., and Dong, S. 2010. The influence of water temperature and ration on the growth, body composition and energy budget of tongue sole (Cynoglossus semilaevis). Aquaculture, 299: 106-114.

Fonds, M., Cronie, R., Vethaak, A. D., and Van der Puyl, P. 1992. Metabolism, food consumption and growth of plaice (Pleuronectes platessa) and flounder (Platichthys flesus) in relation to fish size and temperature. Netherlands Journal of Sea Research, 29: $127-143$.

Fonds, M., Tanaka, M., and Van der Veer, H. W. 1995. Feeding and growth of juvenile Japanese flounder Paralichthys olivaceus in relation to temperature and food supply. Netherlands Journal of Sea Research, 34: 111-118.

Fry, F. E. J. 1971. The effect of environmental factors on the physiology of fish. In Fish Physiology. Volume VI, Environmental Relations and Behavior, pp. 1-98. Ed. by W. S. Hoar and D. J. Randall. Academic Press, New York. 559 pp.

Galbraith, P. S., Chassé, J., Caverhill, C., Nicot, P., Gilbert, D., Lefaivre, D., and Lafleur, C. 2019. Conditions océanographiques physiques dans le golfe du Saint-Laurent en 2018. DFO Can. Sci. Advis. Sec. Res. Doc. 2019/046: iv + 83 p.

Ghinter, L., Lambert, Y., and Audet, C. 2019. Influence of sex on growth of juvenile Greenland halibut (Reinhardtius hippoglossoides) in the Estuary and Gulf of St. Lawrence. Fisheries Research, 219. 
513 Gilbert, D. 2004. Propagation of temperature signals from the northwest Atlantic continental

514 shelf edge into the Laurentian Channel. ICES CM, 2004/N:07: 12.

515 Handeland, S. O., Imsland, A. K., and Stefansson, S. O. 2008. The effect of temperature and

516 fish size on growth, feed intake, food conversion efficiency and stomach evacuation rate 517 of Atlantic salmon post-smolts. Aquaculture, 283: 36-42.

518 Hidalgo, F., Alliot, E., and Thebault, H. 1987. Influence of water temperature on food intake, 519 food efficiency and gross composition of juvenile sea bass, Dicentrarchus labrax. $520 \quad$ Aquaculture, 64: 199-207.

521 Horodysky, A. Z., Cooke, S. J., and Brill, R. W. 2015. Physiology in the service of fisheries 522 science: Why thinking mechanistically matters. Reviews in Fish Biology and Fisheries, $523 \quad 25: 425-447$.

524 Imsland, A. K., Foss, A., Gunnarsson, S., Berntssen, M. H. G., FitzGerald, R., Bonga, S. W., 525 Ham, E. v., Nævdal, G., Stefansson, S. 2001. The interaction of temperature and salinity 526 on growth and food conversion in juvenile turbot (Scophthalmus maximus). Aquaculture, $527 \quad 198: 353-367$.

Imsland, A. K., Foss, A., Folkvord, A., Stefansson, S. O., and Jonassen, T. M. 2005. The interrelation between temperature regimes and fish size in juvenile Atlantic cod (Gadus 530 morhua): Effects on growth and feed conversion efficiency. Fish Physiology and $531 \quad$ Biochemistry, 31: 347-361.

Jobling, M. 1993. Bioenergetics: feed intake and energy partioning. In Fish ecophysiology, pp. 1-44. Ed. by J. C. Rankin and F. B. Jensen. Chapman and Hall, London.

534 Kaplan, E. L., and Meier, P. 1958. Nonparametric estimation from incomplete observations. 535 Journal of the American Statistical Association, 53: 457-481. 
Karl, H., Numata, J., and Lahrssen-Wiederholt, M. 2018. Variability of fat, water and protein content in the flesh of beaked redfish (Sebastes mentella) and Greenland halibut (Reinhardtius hippoglossoides) from artic fishing grounds. Journal of Consumer Protection and Food Safety, 13: 383-389.

Lloret, J., Shulman, G., and Love, R. 2014. Condition and health indicators of exploited marine fishes. Oxford. $247 \mathrm{pp}$.

Mattson, N. S., and Riple, T. H. 1989. Metomidate, a better anesthetic for Cod (Gadus morhua) in comparison with bezocaine,MS-222,chlorobutanol, and phenoxyethanol. Aquaculture, 83: 89-94.

Mazeaud, M. M., Mazeaud, F., and Donaldson, E. M. 1977. Primary and secondary effects of stress in fish: Some new data with a general review. Transactions of the American Fisheries Society, 106: 201-212.

Methven, D. A., Crim, L. W., Norberg, B., Brown, J. A., and Goff, G. P. 1992. Seasonal reproduction and plasma levels of sex steroids and vitellogenin in Atlantic halibut (HippogIossus hippoglossus). Canadian Journal of Fisheries and Aquatic Sciences, 49: $754-759$.

Morgan, M. J., Bowering, W. R., Gundersen, A. C., Høines, Å., Morin, B., Smirnov, O., and Hjörleifsson, E. 2003. A comparison of the maturation of Greenland halibut (Reinhardtius hippoglossoides) from populations throughout the North Atlantic. Journal of Northwest Atlantic Fishery Science, 31: 99-112.

Morgan, M. J., Garabana, D., Rideout, R. M., and Roma, E. 2013. Changes in distribution of Greenland halibut in a varying environment. ICES Journal of Marine Science, 70: 352361. 
Morrison, C. M. 1990. Histology of the Atlantic cod, Gadus morhua: an atlas. Part three. Reproductive tract. Canadian Special Publications of Fisheries and Aquatic Sciences, 110: $177 \mathrm{p}$.

Neuheimer, A. B., and Taggart, C. T. 2007. The growing degree-day and fish size-at-age: The overlooked metric. Canadian Journal of Fisheries and Aquatic Sciences, 64: 375-385.

Neuheimer, A. B., Thresher, R. E., Lyle, J. M., and Semmens, J. M. 2011. Tolerance limit for fish growth exceeded by warming waters. Nature Climate Change, 1: 110-113.

Norberg, B., Weltzien, F., Karlsen, Ø., and Holm, J. C. 2001. Effects of photoperiod on sexual maturation and somatic growth in male Atlantic halibut (Hippoglossus hippoglossus L .). Comparative Biochemistry and Physiology, Part B, 129: 357-365.

Pickering, A. D., and Pottinger, T. G. 1989. Stress responses and disease resistance in salmonid fish: Effects of chronic elevation of plasma cortisol. Fish Physiology and Biochemistry, 7: 253-258.

Pörtner, H. O., Schulte, P. M., Wood, C. M., and Schiemer, F. 2010. Niche dimensions in fishes: An integrative view. Physiological and Biochemical Zoology, 83: 808-826.

Rideout, R. M., Morgan, M. J., Lambert, Y., Cohen, A. M., Banoub, J. H., and Treble, M. 2012. Oocyte development and vitellogenin production in Northwest Atlantic Greenland halibut Reinhardtius hippoglossoides. Journal of Northwest Atlantic Fishery Science, 44: $15-29$.

Russel, N. R., Fish, J. D., and Wooton, R. J. 1996. Feeding and growth of juvenile sea bass: the effect of ration and temperature on growth rate and efficiency. Journal of Fish Biology, 49: 206-220.

Scott, W. B., and Scott, M. G. 1988. Atlantic fishes of Canada. Canadian Bulletin of Fisheries 
and Aquatic Sciences, 219:xxx + $731 \mathrm{pp}$.

583

584

585

586

587

588

589

590

591

592

593

594

595

596

597

598

599

600

601

602

603

604

Solmundsson, J. 2007. Trophic ecology of Greenland halibut (Reinhardtius hippoglossoides) on the Icelandic continental shelf and slope. Marine Biology Research, 3: 231-242.

Steffel, S., Magnuson, J. J., Dizon, A. E., and Neill, W. H. 1976. Temperature discrimination by captive free-swimming tuna, Euthynnus affinis. Transactions of the American Fisheries Society, 105: 588-591.

Sulikowski, J. A., Tsang, P. C. W., and Howell, W. H. 2005. Age and size at sexual maturity for the winter skate, Leucoraja ocellata, in the western Gulf of Maine based on morphological, histological and steroid hormone analyses. Environmental Biology of Fishes, 72: 429-441.

Sünksen, K., Stenberg, C., and Grønkjær, P. 2010. Temperature effects on growth of juvenile Greenland halibut (Reinhardtius hippoglossoides Walbaum) in West Greenland waters. Journal of Sea Research, 64: 125-132.

Treble, M. A., Campana, S. E., Wastle, R. J., Jones, C. M., and Boje, J. 2008. Growth analysis and age validation of a deepwater Arctic fish, the Greenland halibut (Reinhardtius hippoglossoides). Canadian Journal of Fisheries and Aquatic Sciences, 65: 1047-1059.

Van der Veer, H. W., Berghahn, R., and Rijnsdorp, A. D. 1994. Impact of juvenile growth on recruitment in flatfish. Netherlands Journal of Sea Research, 32: 153-173.

Van der Veer, H. W., Berghahn, R., Miller, J. M., and Rijnsdorp, A. D. 2000. Recruitment in flatfish, with special emphasis on North Atlantic species: Progress made by the Flatfish Symposia. ICES Journal of Marine Science, 57: 202-215.

Van der Veer, H. W., Freitas, V., and Leggett, W. C. 2015. Recruitment level and variability. In Flatfishes: biology and exploitation, John Wiley, pp. 185-206. Ed. by R. N. Gibson, R. 

pp.

607 Van Ham, E. H., Berntssen, M. H. G., Imsland, A. K., Parpoura, A. C., Wendelaar Bonga, S. 608 E., and Stefansson, S. O. 2003. The influence of temperature and ration on growth, feed 609 conversion, body composition and nutrient retention of juvenile turbot (Scophthalmus 610 maximus). Aquaculture, 217: 547-558.

611 Victorero, L., Watling, L., Deng Palomares, M. L., and Nouvian, C. 2018. Out of sight, but 612 within reach: A global history of bottom-trawled deep-sea fisheries from $>400 \mathrm{~m}$ depth. $613 \quad$ Marine Science, 5: 1-17.

614 Vollen, T., and Albert, O. T. 2008. Pelagic behaviour of adult Greenland Halibut. Fishery $615 \quad$ Bulletin, 106: 457-470.

616 Wheeland, L. J., and Morgan, M. J. 2019. Age-specific shifts in Greenland halibut 617 (Reinhardtius hippoglossoides) distribution in response to changing ocean climate. ICES 618 Journal of Marine Science.

619 Xiaojun, X., and Ruyung, S. 1992. The bioenergetics of the southern catfish (Silurus 620 meridionalis Chen): Growth rate as a function of ration level, body weight and 621 temperature. Journal of Fish Biology, 40: 719-730. 
622

623

624

626

627

628

629

630

631

632

633

634

635

636

637

638

639

640

641

642

643

644

645

\section{Figure Caption}

Figure 1: Cumulative proportion of survival (Kaplan-Meier analysis) in juvenile Greenland halibut reared at $4.0,5.5$, or $7.5^{\circ} \mathrm{C}$ for one year. The censored data, unlike the complete data, correspond to individuals who survived until the end of the experiment but who could have died due to temperature effect after the end of the experiment. Number of died females (F), males (M), and fish of undetermined sex (NA) are indicated in parentheses below the temperature. Each point represents one fish.

Figure 2: Length (A) and mass (B) plotted against degree-days in juvenile Greenland halibut reared at $4.0,5.5$, or $7.5^{\circ} \mathrm{C}$ for one year. Each point represents the average length or mass in one tank. Different superscript letters $(a, b)$ indicate significant differences between slopes.

Figure 3: Fulton condition index plotted against degree-days in juvenile Greenland halibut. Individuals reared at $4.0,5.5$, or $7.5^{\circ} \mathrm{C}$ for one year were pooled in the analyse due to absence of temperature effect. Each point represents the average condition index in one tank. Linear regression: $\mathrm{R}^{2}=0.72 ; \mathrm{F}_{1,70}=179.69, \mathrm{P}<0.001$.

Figure 4: Length (A) and mass (B) plotted against degree-days for female (black line and squares) and male (white circle and dotted line) juvenile Greenland halibut reared at 4.0 (1), 5.5 (2), or $7.5^{\circ} \mathrm{C}$ (3) for one year. Each point represents one juvenile. * indicates a significant difference $(\mathrm{P} \leq 0.05)$ between slopes.

Figure 5: Linear regression of plasma $17 \beta$-estradiol as a function of female juvenile length $\left(1.1316+0.1025 \mathrm{x}, \mathrm{R}^{2}=0.37, \mathrm{~F}_{1,117}=67.71, \mathrm{P}<0.001\right)$. Data for each temperature and each sampling date were pooled because there was no temperature effect or sampling date effect to test for the size effect. Statistical analysis was done on log-transformed data. 
646 Table 1: Initial average length and mass of juveniles (average per tank; $\mathrm{N}=8$ for each 647 temperature treatment). The results are expressed as mean $\pm \mathrm{SD}$.

648 Table 2: Summary of linear regression parameters for lengths and masses with degree-days 649 (Figure 2). $* *=\mathrm{P} \leq 0.01 ; * * *=\mathrm{P} \leq 0.001$. The results of the slope comparisons are indicated 650 for each temperature. Different superscript letters $(a, b)$ indicate significant differences.

651 Table 3: Average Fulton condition index of juveniles at each temperature and sampling date 652 (average per tank; $\mathrm{N}=8$ for each temperature treatment and sampling date). The results are 653 expressed as mean $\pm \mathrm{SD}$.

654 Table 4: Average food intake per juvenile $\left(\mathrm{g} \mathrm{d}^{-1}\right)$ per temperature and experimental period. 655 The results are expressed as mean $\pm \mathrm{SD}$. The tank is the statistical unit. Different superscript 656 letters $(\mathrm{a}, \mathrm{b})$ indicate differences among the means (significant temperature $\times$ period 657 interaction, see the Results section).

658 Table 5: Initial average length and mass of female and males juvenile Greenland halibut. The 659 results are expressed as mean $\pm \mathrm{SD}$.

660 Table 6: Summary of linear regression parameters for lengths and masses with degree-days 661 (Figure 4). * ${ }^{*} \mathrm{P} \leq 0.05 ; * *=\mathrm{P} \leq 0.01 ; * * *=\mathrm{P} \leq 0.001$.

662 Table 7: Average Fulton condition index of juveniles at each sampling date. The results are 663 expressed as mean $\pm \mathrm{SD} . * *=\mathrm{P} \leq 0.01$

664 Table 8: Summary of ANOVA analyses. The statistical unit is the individual. $*=\mathrm{P} \leq 0.05$; $665 * * *=\mathrm{P} \leq 0.001$. 


\begin{tabular}{|c|c|c|c|c|c|c|c|}
\hline \multirow[b]{2}{*}{ Temperature } & \multicolumn{3}{|c|}{ Initial conditions } & \multicolumn{4}{|c|}{ One-way ANOVA } \\
\hline & $4.0^{\circ} \mathrm{C}$ & $5.5^{\circ} \mathrm{C}$ & $7.5^{\circ} \mathrm{C}$ & $d f$ & $d f($ error $)$ & $\mathrm{F}$ & $P$ value \\
\hline Length $(\mathrm{cm})$ & $27.1 \pm 1.5$ & $26.6 \pm 1.6$ & $27.1 \pm 1.8$ & 2 & 21 & 0.32 & $>0.05$ \\
\hline Mass (g) & $156.6 \pm 25.0$ & $149.6 \pm 19.6$ & $155.5 \pm 29.5$ & 2 & 21 & 0.18 & $>0.05$ \\
\hline
\end{tabular}




\begin{tabular}{ccccccc}
\hline Length & equation & $\mathrm{R}^{2}$ & $d f$ & $d f$ (error) & $\mathrm{F}$ & $P$ value \\
\cline { 2 - 7 } $4.0^{\circ} \mathrm{C}^{\mathrm{a}}$ & $27.1106+0.0044 \mathrm{x}$ & 0.72 & 1 & 22 & 55.65 & $* * *$ \\
$5.5^{\circ} \mathrm{C}^{\mathrm{a}}$ & $26.8153+0.0039 \mathrm{x}$ & 0.82 & 1 & 22 & 103.04 & $* * *$ \\
$7.5^{\circ} \mathrm{C}^{\mathrm{b}}$ & $27.4153+0.0022 \mathrm{x}$ & 0.53 & 1 & 22 & 24.70 & $* * *$ \\
& Slope homogeneity & & 2 & 66 & 6.10 & $* *$ \\
Mass & & & & & & \\
$4.0^{\circ} \mathrm{C}^{\mathrm{a}}$ & $154.5493+0.1390 \mathrm{x}$ & 0.75 & 1 & 22 & 66.62 & $* * *$ \\
$5.5^{\circ} \mathrm{C}^{\mathrm{a}}$ & $152.0815+0.1304 \mathrm{x}$ & 0.87 & 1 & 22 & 152.95 & $* * *$ \\
$7.5^{\circ} \mathrm{C}^{\mathrm{b}}$ & $164.7043+0.0746 \mathrm{x}$ & 0.61 & 1 & 22 & 34.22 & $* * *$ \\
& Slope homogeneity & & 2 & 66 & 7.74 & $* * *$ \\
\hline
\end{tabular}




\begin{tabular}{|c|c|c|c|c|c|c|c|}
\hline \multirow{3}{*}{$\begin{array}{c}\text { Temperature } \\
\text { July } \\
\text { (begining) }\end{array}$} & \multicolumn{3}{|c|}{ Fulton condition index } & \multicolumn{4}{|c|}{ One-way ANOVA } \\
\hline & $4.0^{\circ} \mathrm{C}$ & $5.5^{\circ} \mathrm{C}$ & $7.5^{\circ} \mathrm{C}$ & $d f$ & $d f($ error $)$ & $\mathrm{F}$ & $P$ value \\
\hline & $0.75 \pm 0.02$ & $0.75 \pm 0.03$ & $0.75 \pm 0.01$ & 2 & 21 & 0.08 & $>0.05$ \\
\hline December & $0.85 \pm 0.03$ & $0.87 \pm 0.02$ & $0.86 \pm 0.04$ & 2 & 21 & 0.67 & $>0.05$ \\
\hline July (end) & $0.88 \pm 0.05$ & $0.92 \pm 0.03$ & $0.89 \pm 0.04$ & 2 & 21 & 1.86 & $>0.05$ \\
\hline
\end{tabular}




\begin{tabular}{|c|c|c|}
\hline \multirow{2}{*}{ Temperature } & \multicolumn{2}{|c|}{ Period } \\
\hline & July-Dec. & Dec.-July \\
\hline $4.0^{\circ} \mathrm{C}$ & $2.07 \square 0.57^{\mathrm{a}}$ & $2.85 \pm 1.14^{\mathrm{a}, \mathrm{b}}$ \\
\hline $5.5^{\circ} \mathrm{C}$ & $2.84 \pm 0.71^{\mathrm{a}}$ & $3.83 \pm 1.28^{b}$ \\
\hline $7.5^{\circ} \mathrm{C}$ & $2.85 \pm 1.07^{\mathrm{a}, \mathrm{b}}$ & $2.55 \pm 1.02^{\mathrm{a}, \mathrm{b}}$ \\
\hline
\end{tabular}




\begin{tabular}{ccccccccc}
\hline & \multicolumn{3}{c}{ Initial conditions } & & \multicolumn{4}{c}{ One-way ANOVA } \\
\cline { 2 - 3 } \cline { 6 - 8 } Sex & $\phi$ & $\delta$ & & $d f$ & $d f($ error $)$ & $\mathrm{F}$ & $P$ value \\
Length $(\mathrm{cm})$ & $25.3 \pm 3.4$ & $27.7 \pm 3.00$ & & 1 & 18 & 2.80 & $>0.05$ \\
Mass $(\mathrm{g})$ & $128.7 \pm 52.6$ & $170.9 \pm 60.6$ & & 1 & 18 & 2.76 & $>0.05$ \\
\hline
\end{tabular}




\begin{tabular}{|c|c|c|c|c|c|c|c|}
\hline Length & & Equation & $\mathrm{R}^{2}$ & $d f$ & $d f$ (error) & $\mathrm{F}$ & $P$ value \\
\hline \multirow[t]{4}{*}{$A, 1\left(4.0^{\circ} \mathrm{C}\right)$} & q & $25.9445+0.0063 x$ & 0.48 & 1 & 43 & 38.92 & $* * *$ \\
\hline & $\delta$ & $27.7152+0.0044 x$ & 0.43 & 1 & 33 & 24.89 & $* * *$ \\
\hline & & Slope homogeneity & & 1 & 76 & 1.99 & $>0.05$ \\
\hline & & $A N C O V A$ & & 1 & 77 & 0.18 & $>0.05$ \\
\hline \multirow[t]{3}{*}{$\mathrm{A}, 2\left(5.5^{\circ} \mathrm{C}\right)$} & q & $26.5639+0.0049 x$ & 0.41 & 1 & 48 & 33.92 & $* * *$ \\
\hline & $\delta$ & $27.3799+0.0027 x$ & 0.31 & 1 & 38 & 17.15 & $* * *$ \\
\hline & & Slope homogeneity & & 1 & 86 & 3.90 & $*$ \\
\hline \multirow[t]{4}{*}{$\mathrm{A}, 3\left(7.5^{\circ} \mathrm{C}\right)$} & q & $26.8730+0.0031 x$ & 0.45 & 1 & 43 & 35.46 & $* * *$ \\
\hline & $\delta$ & $28.3180+0.0019 x$ & 0.19 & 1 & 43 & 10.14 & $* *$ \\
\hline & & Slope homogeneity & & 1 & 86 & 2.38 & $>0.05$ \\
\hline & & ANCOVA & & 1 & 87 & 0.24 & $>0.05$ \\
\hline \multicolumn{8}{|l|}{ Mass } \\
\hline \multirow[t]{4}{*}{$\mathrm{B}, 1\left(4.0^{\circ} \mathrm{C}\right)$} & q & $126.3498+0.2191 x$ & 0.44 & 1 & 43 & 33.25 & $* * *$ \\
\hline & $\delta$ & $165.8713+0.1320 x$ & 0.43 & 1 & 33 & 24.95 & $* * *$ \\
\hline & & Slope homogeneity & & 1 & 76 & 3.36 & $>0.05$ \\
\hline & & ANCOVA & & 1 & 77 & 0.88 & $>0.05$ \\
\hline \multirow[t]{4}{*}{$\mathrm{B}, 2\left(5.5^{\circ} \mathrm{C}\right)$} & $q$ & $152.1798+0.1615 x$ & 0.36 & 1 & 48 & 27.09 & $* * *$ \\
\hline & $\delta$ & $178.6109+0.0975 x$ & 0.35 & 1 & 38 & 20.10 & $* * *$ \\
\hline & & Slope homogeneity & & 1 & 86 & 2.71 & $>0.05$ \\
\hline & & $A N C O V A$ & & 1 & 87 & 2.19 & $>0.05$ \\
\hline \multirow[t]{4}{*}{$\mathrm{B}, 3\left(7.5^{\circ} \mathrm{C}\right)$} & q & $158.6343+0.0990 x$ & 0.41 & 1 & 43 & 29.92 & $* * *$ \\
\hline & $\delta$ & $186.9149+0.0635 x$ & 0.19 & 1 & 43 & 10.12 & $* *$ \\
\hline & & Slope homogeneity & & 1 & 86 & 1.73 & $>0.05$ \\
\hline & & $A N C O V A$ & & 1 & 87 & 0.82 & $>0.05$ \\
\hline
\end{tabular}




\begin{tabular}{cccccccc}
\hline & \multicolumn{3}{c}{ Fulton condition index } & & \multicolumn{4}{c}{ One-way ANOVA } \\
\cline { 2 - 3 } Sex & $q$ & $\delta$ & & $d f$ & $d f($ error $)$ & F & $P$ value \\
July (begining) & $0.75 \pm 0.06$ & $0.78 \pm 0.10$ & & 1 & 18 & 0.59 & $>0.05$ \\
December & $0.89 \pm 0.10$ & $0.84 \pm 0.08$ & & 1 & 88 & 6.69 & $* *$ \\
July (end) & $0.95 \pm 0.11$ & $0.88 \pm 0.13$ & & 1 & 108 & 7.70 & $* *$ \\
\hline
\end{tabular}




\begin{tabular}{|c|c|c|c|c|}
\hline \multirow[b]{2}{*}{ Muscle energy } & \multicolumn{4}{|c|}{ ANOVAs } \\
\hline & $d f$ & $d f($ error $)$ & $\mathrm{F}$ & $P$ value \\
\hline Sampling date & 1 & 188 & 0.29 & $>0.05$ \\
\hline Sex & 1 & 188 & 0.13 & $>0.05$ \\
\hline Temperature & 2 & 188 & 0.73 & $>0.05$ \\
\hline Sampling date $\times$ Sex & 1 & 188 & 2.26 & $>0.05$ \\
\hline Sampling date $\times$ Temperature & 2 & 188 & 0.28 & $>0.05$ \\
\hline Sex $\times$ Temperature & 2 & 188 & 0.62 & $>0.05$ \\
\hline $\begin{array}{c}\text { Sampling date } \times \text { Sex } \times \text { Temperature } \\
\text { Cortisol }\end{array}$ & 2 & 188 & 0.46 & $>0.05$ \\
\hline Sampling date & 1 & 188 & 3.68 & $>0.05$ \\
\hline Sex & 1 & 188 & 2.35 & $>0.05$ \\
\hline Temperature & 2 & 188 & 3.33 & $*$ \\
\hline Sampling date $\times$ Sex & 1 & 188 & 0.57 & $>0.05$ \\
\hline Sampling date $\times$ Temperature & 2 & 188 & 0.13 & $>0.05$ \\
\hline Sex $\times$ Temperature & 2 & 188 & 0.22 & $>0.05$ \\
\hline $\begin{array}{l}\text { Sampling date } \times \text { Sex } \times \text { Temperature } \\
\text { 11-ketotestosterone }(\delta)\end{array}$ & 2 & 188 & 2.03 & $>0.05$ \\
\hline Sampling date & 1 & 84 & 0.31 & $>0.05$ \\
\hline Temperature & 2 & 84 & 2.41 & $>0.05$ \\
\hline $\begin{array}{c}\text { Sampling date } \times \text { Temperature } \\
\text { 17ß-estradiol }(q)\end{array}$ & \multicolumn{3}{|c|}{ 17及-estradiol $(q)$} & $>0.05$ \\
\hline Sampling date & 1 & 104 & 11.66 & $* * *$ \\
\hline Temperature & 2 & 104 & 0.66 & $>0.05$ \\
\hline Sampling date $\times$ Temperature & 2 & 104 & 0.67 & $>0.05$ \\
\hline
\end{tabular}




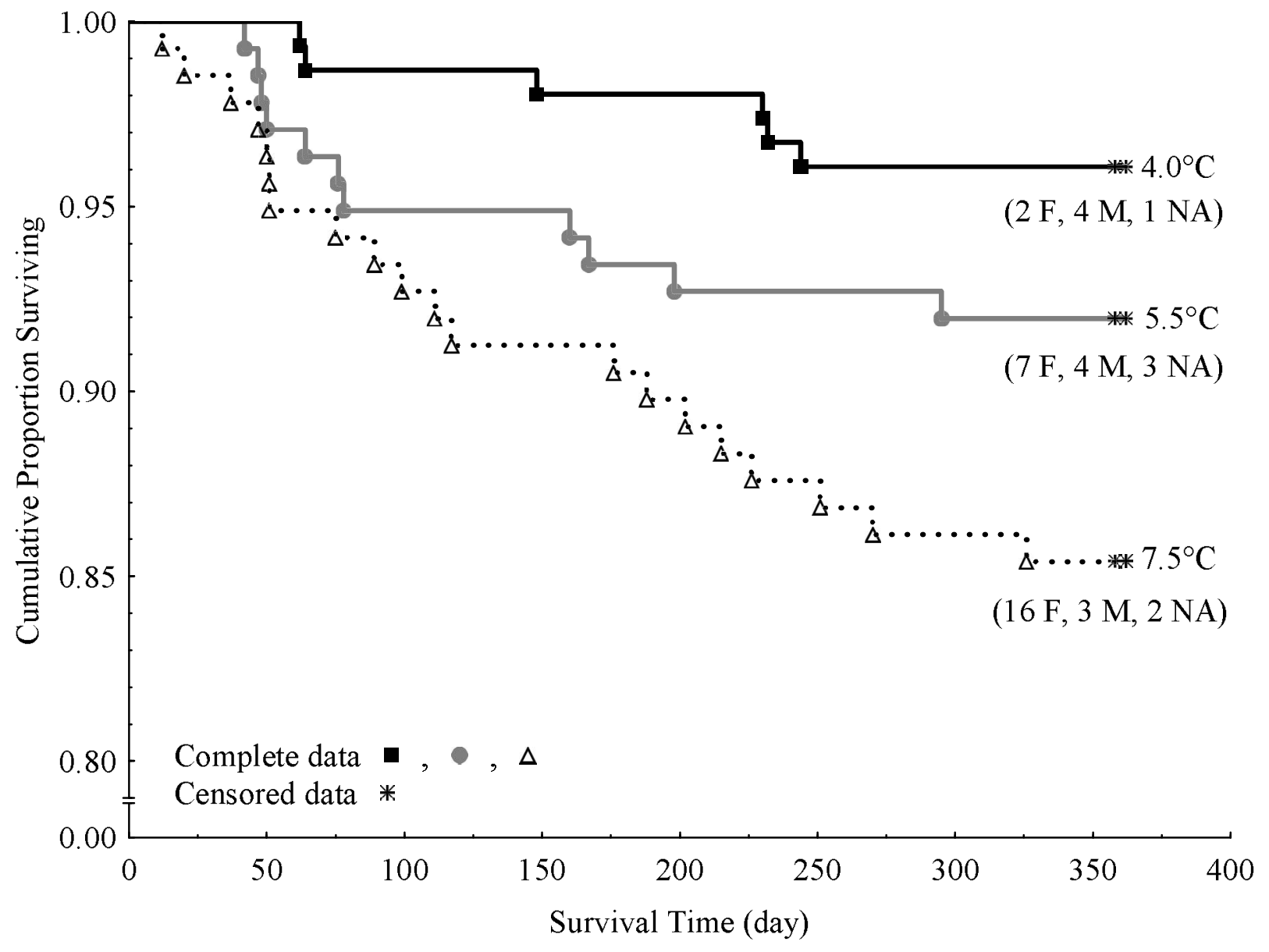



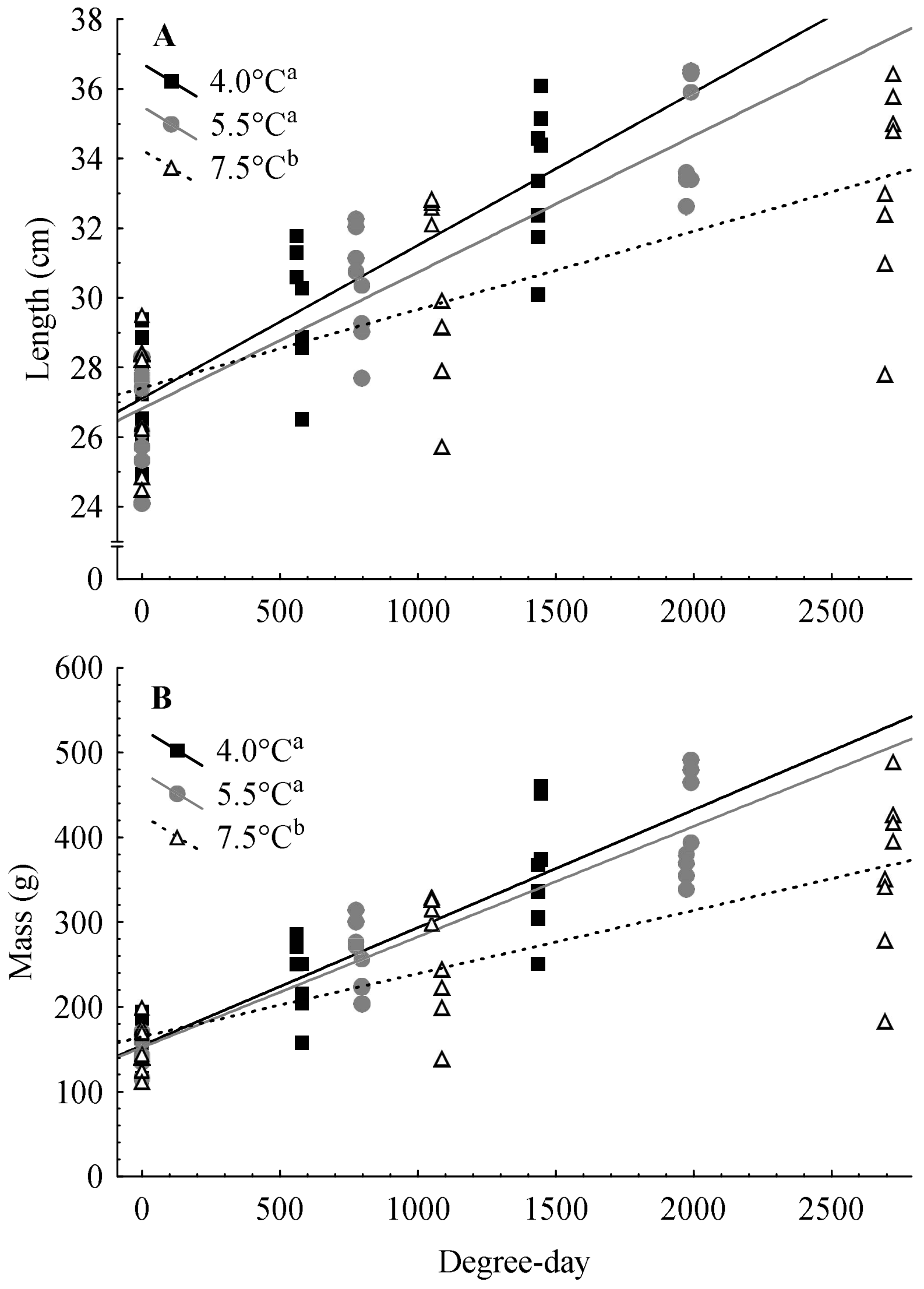


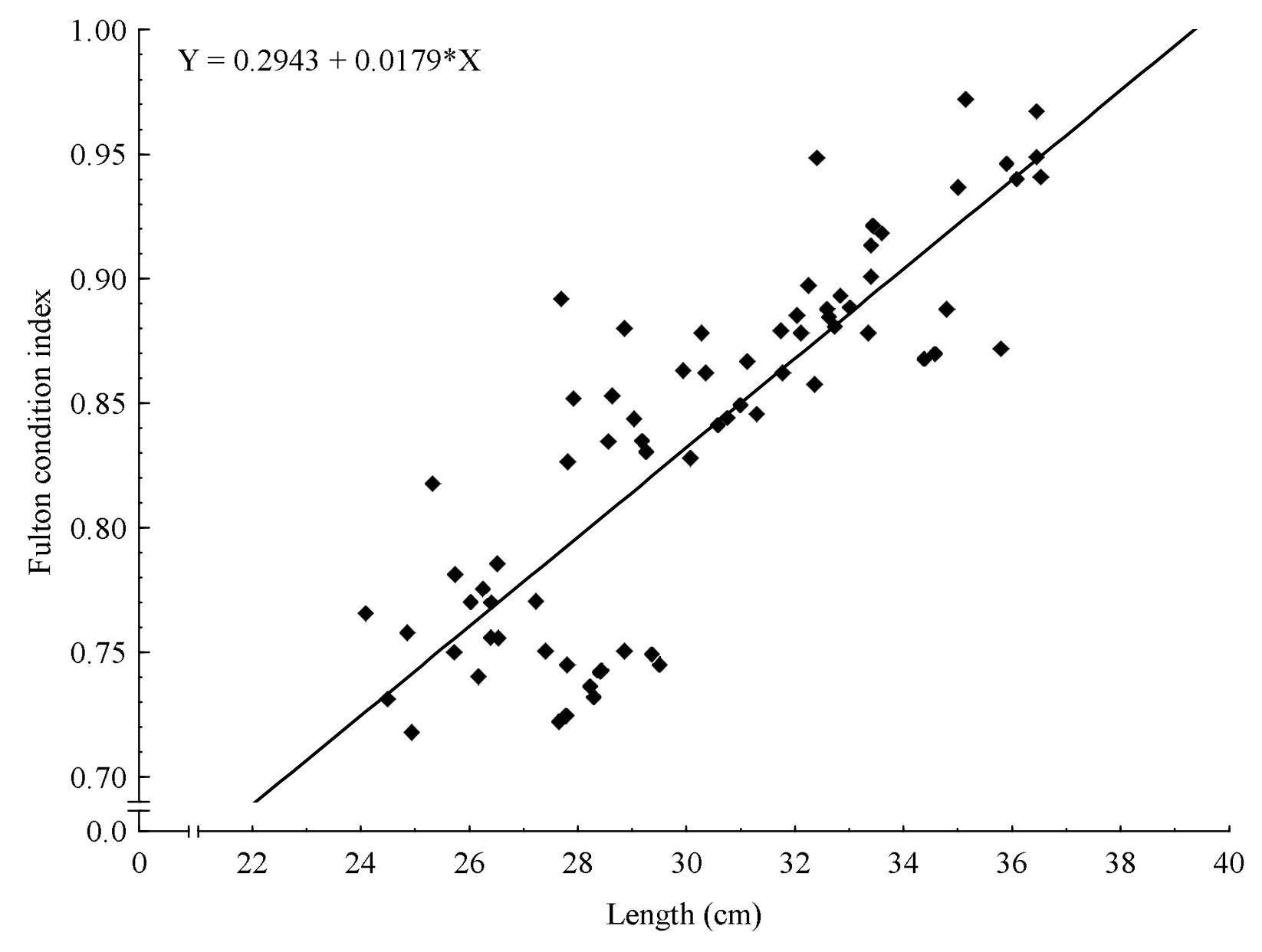

Figure 3 

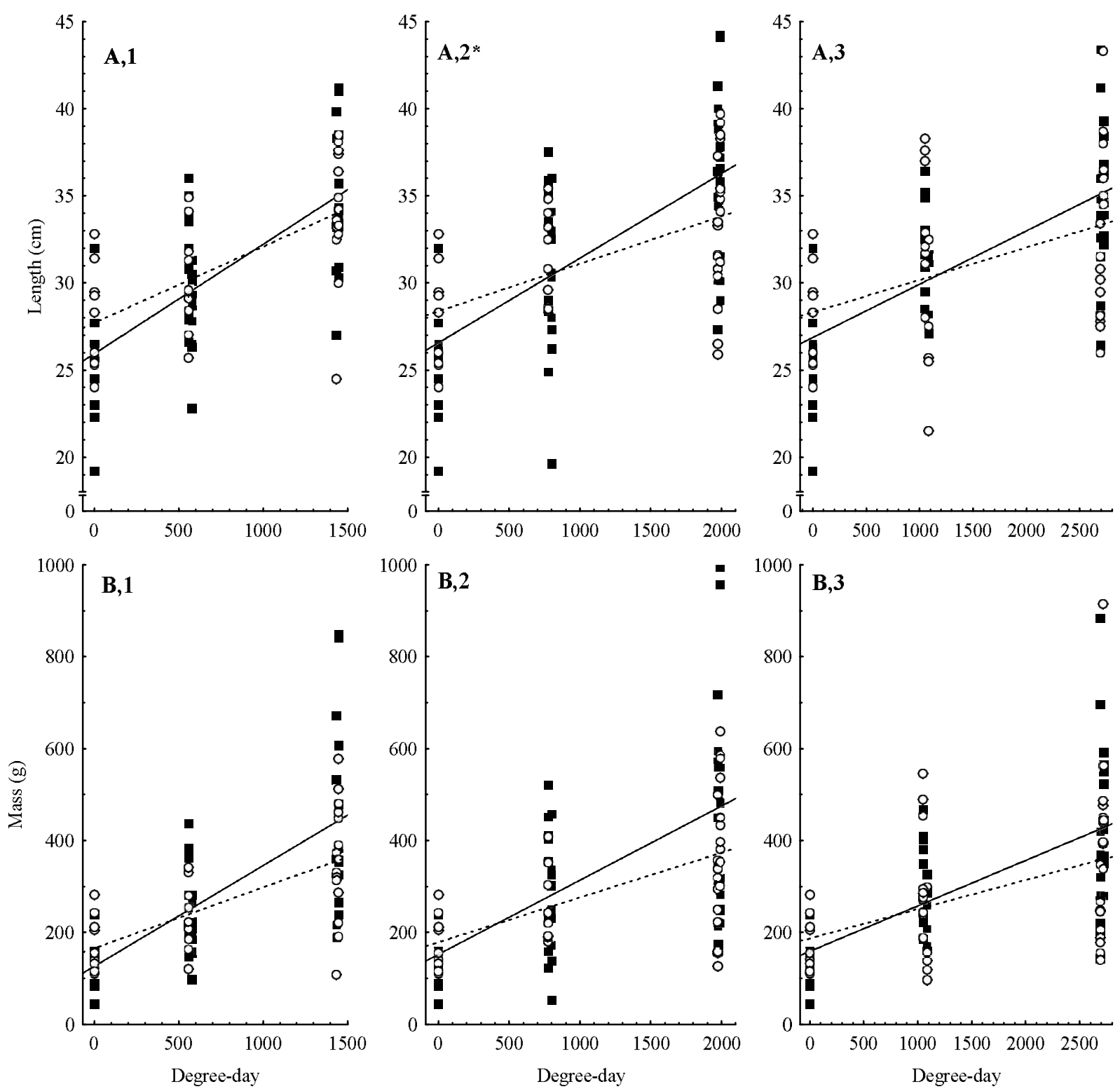


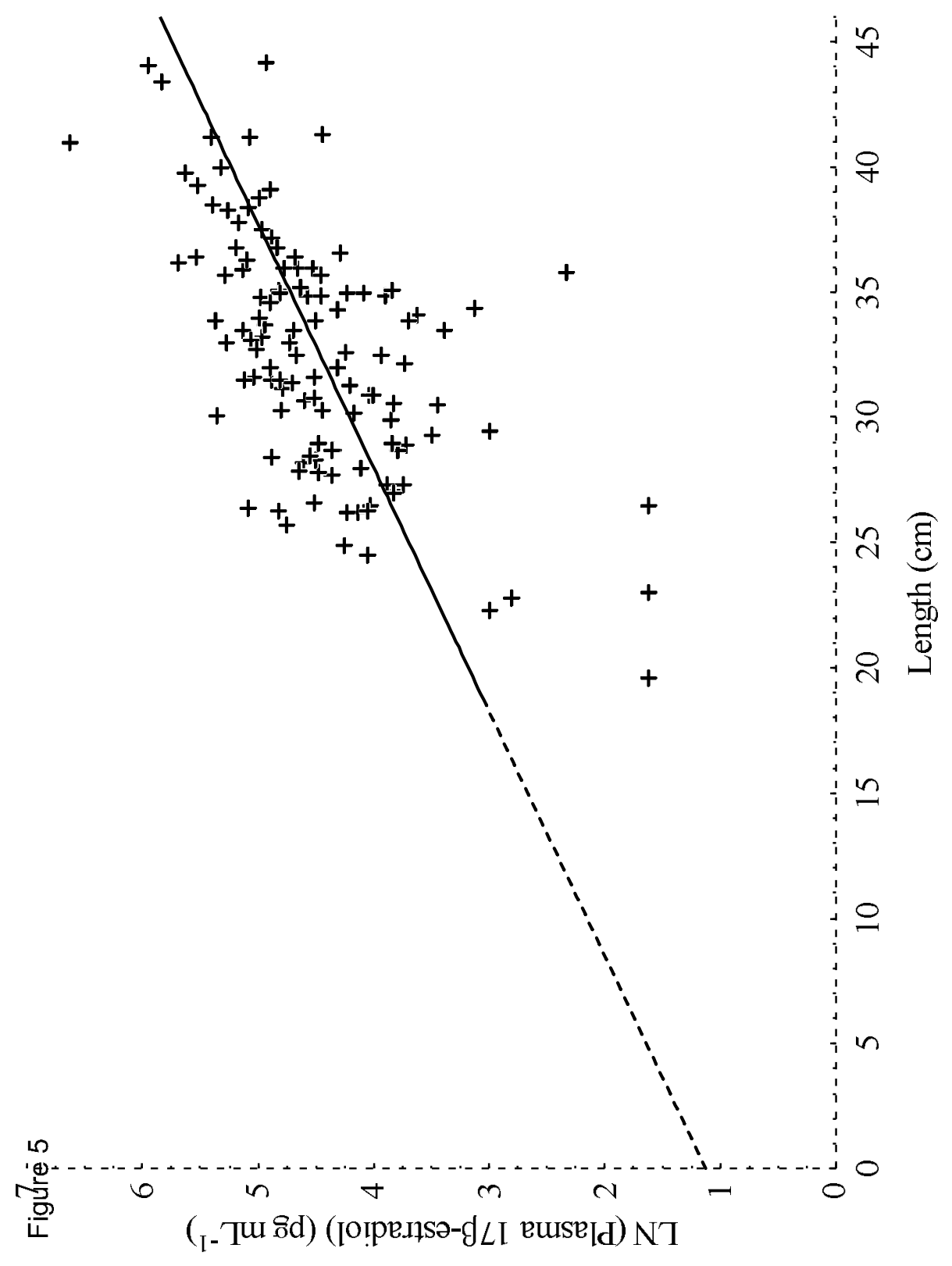




\section{Authorship statements}

Ghinter: Conceptualization, Data curation, Formal analysis, Investigation, Methodology, Validation, Visualization, Writing - original draft.

Lambert: Conceptualization, Data curation, Funding acquisition, Investigation, Methodology, Resources, Supervision, Validation, Writing - review and editing.

Audet: Conceptualization, Data curation, Funding acquisition, Investigation, Methodology, Project administration, Resources, Supervision, Validation, Writing review and editing. 


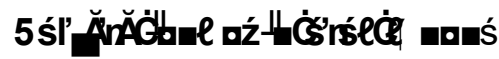

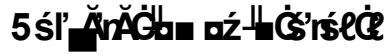

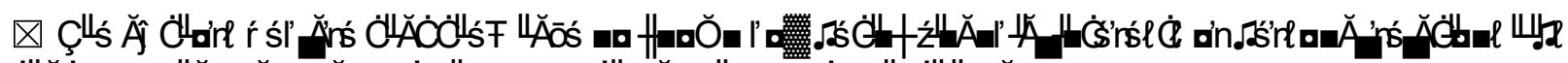

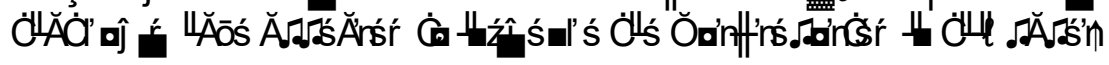

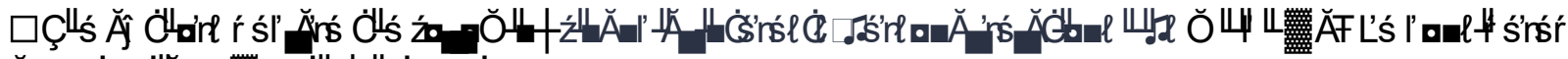

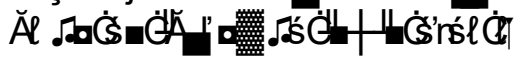

